\title{
支承特性差に着目した 橋梁振動応答特性に関する研究
}

\author{
山田均 $1 \cdot$ 沢田 繁樹 $2 \cdot$ 篠原 修二 $3 \cdot$ 風間 浩二 4
}

\begin{abstract}
1 正会員 横浜国立大学 教授 工学部 建設学科 (广240-8501 横浜市保土ヶ谷区常盤台79-5)

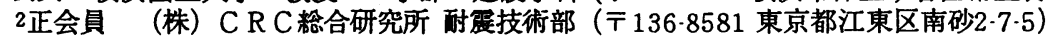

3 正会員 (株) 綜合技術ン州多ント技術第一部部長（广101-0051 東京都千代田区神田小川町3-1） 4 正会員 住友重機械工業（株）鉄構機器事業本部課長代理（广141-8686 東京都品川区北品川 5-9-11）
\end{abstract}

\begin{abstract}
兵庫県南部地震以降, 橋梁構造物や建築榡造物では免震構造物が多く建造されている. 具体的な免震装 置としては，構造の単純さと経済的に優れた点が評価されて積層ゴムタイブの支承が採用される機会が多 くなっている.これらゴム支承は，想定した地震に対して所要のアイソレータ機能及び復元力特性を発揮 するよう設計されるが, 振動モードによっては, 常時の動的交通荷重や風に起因する振動を助長すること が㥿念される．本論文では，简単な橋梁モデルを用い，支承部（銅製支承，積層型コム支承）の特性差 が, 橋梁の固有振動特性や振動応答特性に及ほす影響について, 数值解析による基礎的な検討結果につい て報告する。
\end{abstract}

Key Words : rubber bearings, bridge vibration, vibration absorber

\section{1.はじめに}

わが国は世界有数の地震国であり, 幾多の地震被 害の経験をもとに, 橋梁の耐震設計においても被害 を軽減するための多く技術開発が行われてきた.

平成 7 年 1 月の兵庫県南部地震の被災を受けて, 建設省からは被災地の復旧のための仕様 1) が出さ れ, 連続高架橋等では免震支承等を用いた弾性固定 方式により地震力を分散させることが望ましいこと が示されている.

また，耐震性の向上のみならず，弾性的な支承の 採用により, 支承本来の変形自由度の確保2)3)や温 度変化による析の伸縮に伴う橋脚への水平力を低減 させることにより上部工の多径間連続化の可能性が 広がり, 走行性の向上, 騒音や振動の軽減4), 維持 管理の向上など利点が多い.

このような理由から, 道路橋においても兵庫県南 部地震以前は鋼製支承が用いられていたが, 地震以 後, 新設橋梁においては大部分がゴム支承を採用す るとともに，既設橋梁においても，鋼製支承からゴ 厶支承への取り替え工事が行われている.

これらゴム支承は，想定した地震に対して所要の アイソレー夕機能と復元力特性を発揮するよう設計 される.ゴム支承を採用した場合，これが摩擦減衰 を持たないことや鉛直方向にも僅かながら変形自由 度を持つ弾性支承であることから，交通振動を対象 とした実測でも必ずしも全ての振動が低減していな
(場合むあり5), 振動モードによっては，動的交通 荷重や風による振動を助長することが数念される.

既に実施されたゴム支承化の報告に於いては，そ の効果について, 水平方向加速度を前提とした耐震 効果の検討や構造の連続化と併せた効果の検討はあ るものの, 支承自体の特性差が橋梁の振動応答特性 に及ぼす影響の基䃈的検討は少ない.

このため，本論文では，鋼製支承からゴム支承へ の置き換えが橋梁の固有振動特性や振動応答特性に 及ほ影響について基礎的な考察を加えることを目 的として，比較的簡単な橋梁モテルを用い，支承部 （鋼製支承，積層型ゴム支承）の構造特性の差がこ れらの特性に与える影響を解析的に検討した.

\section{2. 解析モテルと解析方法}

\section{（1） 解析モテル}

解析対象は，モデの一般性を考虑しながら，3 径間連続析橋（桁幅 $11 \mathrm{~m}$, 鋼床版 2 箱桁, 支間長 $\mathrm{L}=100 \mathrm{~m}$ 及び $150 \mathrm{~m}$ ）を例題として取り上げた.これ ら 2 つ支間モテルに対して, 鋼製支承(BP沓) 之積層型ゴム支承（以下ゴム支承）の 2 種類をそれ ぞれ適用した場合の固有振動特性及び振動応答特性 を比較検討することとした.

具体的な解析モテルは図-1 に示す平面骨組みモ テルとした. 支承部は水平, 鉛直, 回転の各ばね要 素でモデ化（図-2）し, 脚下端は固定とした. 


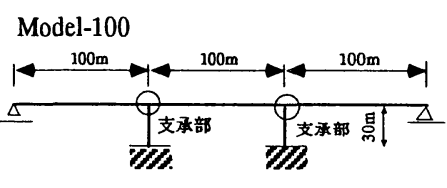

Model-150

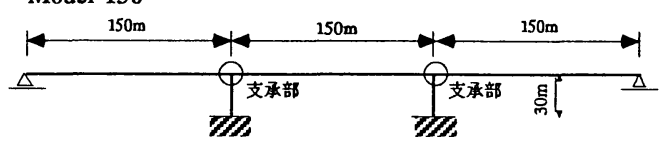

図-1 解析対象橋梁モデル

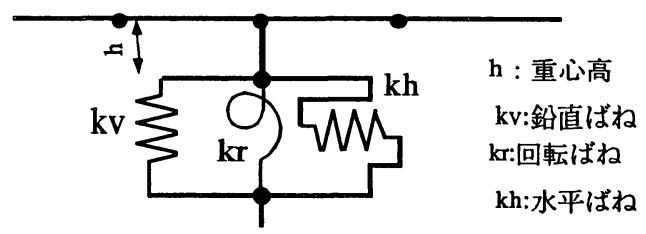

図-2 支承部の解析モテル化

表-1 モデル諸元

\begin{tabular}{|c|c|c|c|}
\hline & model100R & model150R & \\
\hline 形式 & \multicolumn{2}{|c|}{3 径間連続箱桁 } & \\
\hline 支承条件 & \multicolumn{2}{|c|}{ Move+Fix+Fix+Move } & \\
\hline 支間割 & $100+100+100$ & $150+150+150$ & $\mathrm{~m}$ \\
\hline 桁剛性:鉛直 & $0.68 \sim 1.12$ & $0.47 \sim 1.76$ & $m^{4}$ \\
\hline 脚岡性:橋軸 & 32.0 & 49.4 & $m^{4}$ \\
\hline $\begin{array}{l}\text { 支点反力 } \\
\text { (端支点) }\end{array}$ & $\begin{array}{l}\mathrm{Rd}=180 \\
\mathrm{RL}=130\end{array}$ & $\begin{array}{l}\mathrm{Rd}=330 \\
\mathrm{RL}=140\end{array}$ & tf \\
\hline 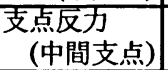 & $\begin{array}{l}\mathrm{Rd}=490 \\
\mathrm{RL}=260\end{array}$ & $\begin{array}{l}\mathrm{Rd}=955 \\
\mathrm{RL}=300\end{array}$ & tf \\
\hline 設計水平震度 & \multicolumn{2}{|c|}{$\mathrm{Kh}=0.2$} & \\
\hline
\end{tabular}

\section{a）鋼製支承部の減衰のモテル化}

鋼製支承部の減衰力は，銅製支承の減衰が摩擦に よるものと仮定した. また，単純化のために，その 振幅依存性を無視し，低次側の振動特性を中心に検 討することから, 鉛直 1 次モードを与える振幅（中 央支間中央部で $0.5 \mathrm{~m})$ を仮定し，摩擦係数に対する 等価摩擦減衰係数を下記の方法で求めた.

減衰は，モデルの性質から，小振幅では過大に， 大振幅では過小に評価される傾向となるため，3つ の值に対して計算を行い比較した.

(1) 1 次モードに着目し, 中央径間中央の鉛直変位を 仮定し，支承部回転変位を定める.

(2)支承部回転変位から桁の鉛直 1 次固有振動数での 回転速度を求める.

$$
\mathrm{Vr}=\mathrm{i} \omega \mathrm{ur}
$$

ここに, Vr: 回転速度, ur : 回転変位, $\omega$ : 桁の固 有円振動数 である.

(3)支承部は点支持と考え，接線方向摩擦力を支承部 回転中心におけるモーメントに置き換え，そのモー メント力を等価な減衰力と仮定し，回転成分等価減
表-2 支承部条件

\begin{tabular}{|l|l|c|c|c|}
\hline \multicolumn{2}{|c|}{} & 水平ばね & 鉛直ばね & 回転ばね \\
\hline 鋼製固定支承 & 剛性 & $\fallingdotseq \infty(0)$ & $\fallingdotseq \infty$ & 0 \\
\cline { 2 - 5 } (可動支承) & 隇衰定数 & 0 & 0 & 摩擦(0) \\
\hline ゴム支承 & 剛性 & 設計値 & 設計値 & 0 \\
\cline { 2 - 5 } & 減衰定数 & $5 \%$ & 0 & 0 \\
\hline
\end{tabular}

表-3 ゴム支承設計諸元（中間支点）

\begin{tabular}{|c|c|c|c|}
\hline & model-100R & model-150R & 単位 \\
\hline 橋軸方向支承幅 & 100 & 135 & $\mathrm{~cm}$ \\
\hline 橋直方向支承幅 & 100 & 135 & $\mathrm{~cm}$ \\
\hline ゴム 1 層厚 & 2.4 & 3.3 & $\mathrm{~cm}$ \\
\hline ゴム層数 & 4 & 4 & \\
\hline ゴム総厚 & 9.6 & 13.2 & $\mathrm{~cm}$ \\
\hline ゴムのG & 10 & 10 & $\mathrm{kgf} / \mathrm{cm}^{2}$ \\
\hline 剪断ばね定数 & 1041.7 & 1380.7 & $\mathrm{tf} / \mathrm{m}$ \\
\hline 形状係数 & 10.42 & 10.23 & \\
\hline 圧縮ばね定数 & 7468.5 & 9544.0 & $\mathrm{tf} / \mathrm{cm}$ \\
\hline 許容圧縮応力度 & 80 & 80 & $\mathrm{kgf} / \mathrm{cm}^{2}$ \\
\hline 圧縮応力度 & $76.1<=80$ & $70.0<=80$ & $\mathrm{kgf} / \mathrm{cm}^{2}$ \\
\hline 常時引張応力度 & $0<=20.0$ & $0<=20.0$ & $\mathrm{kgf} / \mathrm{cm}^{2}$ \\
\hline 地震時引張応力度 & $14.7<=20.0$ & $15.7<=20.0$ & $\mathrm{kgf} / \mathrm{cm}^{2}$ \\
\hline 局部ひずみ $\gamma \mathrm{c}$ & 0.940 & 0.881 & \\
\hline 局部ひずみ $\gamma \mathrm{S}$ & 0.156 & 0.170 & \\
\hline 局部ひずみ $\gamma \mathrm{R}$ & 0.723 & 0.697 & \\
\hline 局部ひずみ 計 & 1.820 & 1.748 & \\
\hline
\end{tabular}

衰係数Crを求める.

$$
\begin{aligned}
& \mathrm{F}=\mu \mathrm{N} \\
& \mathrm{M}=\mathrm{Fh} \\
& \mathrm{Cr}=\mathrm{M} / \mathrm{Vr}
\end{aligned}
$$

$\mathrm{F}$ : 接線方向摩擦力 (ton)

$\mathbf{M}$ : 支承部回転中心モーメント (ton・m)

$\mathrm{h}$ : 支持点から回転中心までの距離 $(\mathrm{m}, 0.1 \mathrm{~m}$ と仮定 $)$

$\mu$ : 摩擦係数, $\mathrm{N}$ : 鉛直力（死荷重）(ton)

$\mathrm{Cr}$ : 等価減衰係数 (ts/rad), $\mathrm{Vr}$ : 回転速度 ( $\mathrm{rad} / \mathrm{sec})$

その他の諸量は標準的な鋼製支承（BP-A）6)を参 照した.

\section{b ）ゴム支承部のモテル化と設計值}

ゴム支承では，水平と鉛直の 2 自由度を弾性と し，回転ばねの剛性を無視した.ゴム支承の支承部 条件を鋼製支承との比較で表- 2 に示す.

また，ゴム支承の設計值諸量を表-3に示す.ゴ 厶支承の設計は，道路橋示方書7)に準じて, 保有水 平耐力法で夕イプ I, II 地震の照查を行った. 中間 支点は水平ばねが線形の分散ゴム支承を使用した。 また，可動支承は剪断変形型の可動支承とした．回 転ばねに対応する減衰は，ゴムのひずみ量が比較的 小さいため,これを無視した. 


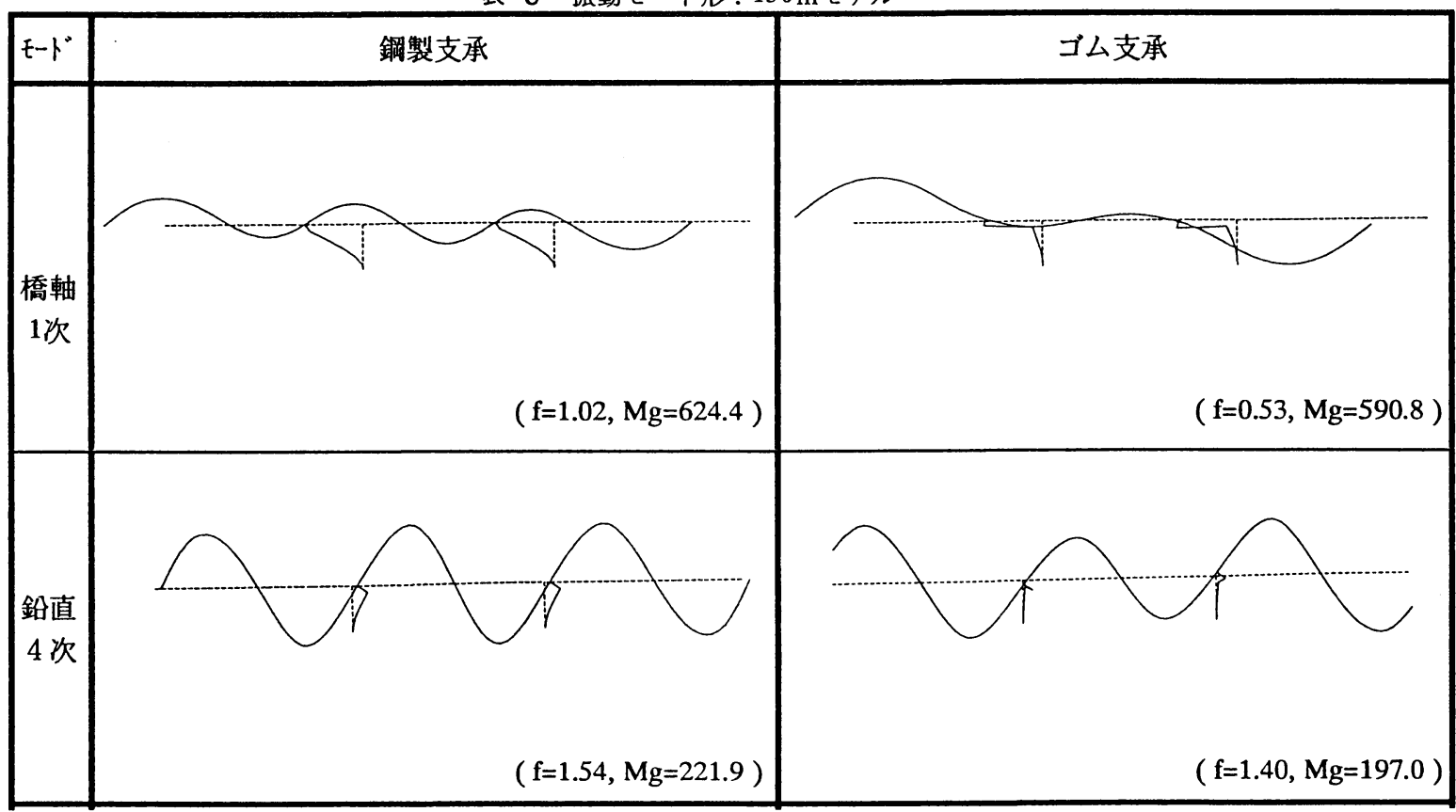

f : 固有振動数 $(\mathrm{Hz}), \mathrm{Mg}:$ －般化質量（各モード最大振幅を 1 として計算）

表-4 固有振動数

\begin{tabular}{|c|c|c|c|c|c|c|}
\hline 支間長 & \multicolumn{2}{|c|}{$100 \mathrm{~m}$} & \multicolumn{3}{|c|}{$150 \mathrm{~m}$} & \\
\hline 支承 & 龬 & ゴム & $\mathrm{R} / \mathrm{S}$ & 鋼 & ゴム & $\mathrm{R} / \mathrm{S}$ \\
\hline 橋軸1次 & 1.11 & 0.61 & 0.55 & 1.02 & 0.53 & 0.52 \\
\hline 鉛直1次 & 0.71 & 0.67 & 0.94 & 0.41 & 0.37 & 0.92 \\
\hline 鉊直2次 & 0.96 & 0.84 & 0.88 & 0.50 & 0.47 & 0.94 \\
\hline 鉛直3次 & 1.35 & 1.13 & 0.83 & 0.87 & 0.80 & 0.92 \\
\hline 鉛直4次 & 2.76 & 2.09 & 0.76 & 1.54 & 1.40 & 0.91 \\
\hline
\end{tabular}

※ 表中R/Sはゴム沓と鋼製沓の值の比である.

\section{（2） 解析方法}

解析は, 支承自体の特性差が橋梁の振動応答特性 に及ぼす影響を調べることを目的として，下記の 3 種の解析を実施した.

(1) 実固有値解析 : 図- 1 に示す解析モデル（1支間 を20節点, 橋脚を10節点に分割）に固有値解析を実 施し, 支承差による固有振動数及び振動モード形の 比較を実施した。

(2) 複素固有值解析 : 図-2に示す支承部のモデル化 で, 鋼製支承には等価減衰係数, コム支承には所定 の減衰定数を与え, 複素固有値解析を実施し, 振動 モード毎のモード減衰を求めた.

(3) 単位振幅加振に対する応答解析 : 振動応答の基 本特性として, 加振外力に対する摇れ易さを把握す るために, 振動モ一ド毎に各振動のモード形の腹の 位置に単位振幅外力を与え。これによるの振動応答 を求めた。

\begin{tabular}{|c|c|c|c|c|c|c|}
\multicolumn{7}{c}{ 表-6 } \\
\multicolumn{1}{c|}{ 一般化質量 } \\
\hline 支間長 & \multicolumn{2}{c|}{$100 \mathrm{~m}$} & & \multicolumn{2}{c|}{$150 \mathrm{~m}$} & \\
\hline 支承 & 鋼 & ゴム & $\mathrm{R} / \mathrm{S}$ & 鋼 & ゴム & $\mathrm{R} / \mathrm{S}$ \\
\hline 橋軸1次 & 366.0 & 274.7 & 0.75 & 624.4 & 590.8 & 0.95 \\
\hline 鉛直1次 & 104.4 & 125.7 & 1.20 & 221.8 & 222.3 & 1.00 \\
\hline 鉛直2次 & 94.1 & 100.4 & 1.07 & 190.1 & 233.1 & 1.23 \\
\hline 鉿直3次 & 68.9 & 69.3 & 1.01 & 69.4 & 73.3 & 1.06 \\
\hline 鉛直4次 & 97.9 & 57.9 & 0.59 & 221.9 & 197.0 & 0.89 \\
\hline
\end{tabular}

※ 表中R/Sはゴム沓と鋼製沓の值の比である.

\section{3. 解析結果と考察}

\section{（1） 固有值解析結果}

固有值解析の結果を表-4に示す. 固有振動数の 順に並へた振動モードは解析モデルによって, 相対位 置が異なったが, ここでは, 振動モード形の順に整 理を行った. 固有振動数は, ゴム支承の設置により 水平モードで約 $40 \sim 50 \%$, 鉛直モードで 5 25\%低下 しでおり, 特に水平モードでの振動数低下が大き い. 固有振動数の低下は, 風による振動（渦励振） の発生風速8)の低下に結びつくため, 注意が必要で ある. 固有値解析結果として得られた振動モード形 の差の顕著なものを表-5に示す. 支承の特性差は固 有値解析の内, 上述の固有振動数のみでなく, 固有 振動モードにも顕著に現れている.

振動モード形を見ると，ゴム支承の鈶直方向の収 縮により支点上変位の差によって振動モード形状に 
表-7 モーダル減衰 : $100 \mathrm{~m}$ モデル

\begin{tabular}{|l|c|c|c|c|}
\hline \multirow{2}{*}{ モ-ト } & \multicolumn{3}{|c|}{ 龬製支承 } & ゴム支承 \\
\cline { 2 - 5 } & $\mu=0.05$ & $\mu=0.10$ & $\mu=0.15$ & - \\
\hline 鉛直1次 & 2.008 & 2.016 & 2.024 & 1.787 \\
\hline 鉛直2次 & 2.004 & 2.006 & 2.008 & 1.483 \\
\hline 鉛直3次 & 2.001 & 2.001 & 2.002 & 1.363 \\
\hline 鉛直4次 & 2.010 & 2.017 & 2.024 & 0.870 \\
\hline
\end{tabular}

表-8 モーダル減衰 : $150 \mathrm{~m}$ モデル

\begin{tabular}{|l|c|c|c|c|}
\hline \multirow{2}{*}{ モート" } & \multicolumn{3}{|c|}{ 龬製支承 } & ゴム支承 \\
\cline { 2 - 5 } & $\mu=0.05$ & $\mu=0.10$ & $\mu=0.15$ & - \\
\hline 鉛直1次 & 2.016 & 2.031 & 2.046 & 1.992 \\
\hline 鉛直2次 & 2.005 & 2.009 & 2.013 & 2.170 \\
\hline 鉛直3次 & 2.005 & 2.010 & 2.014 & 1.690 \\
\hline 鉛直4次 & 2.032 & 2.048 & 2.065 & 1.643 \\
\hline
\end{tabular}

差が見られる. 特に, 振動応答に関する指標を得る ために，各振動モードの最大振幅を 1 として基準化 したモードに対しての一般化質量及び，ゴム支承と 鋼製支承との比を表- 6 に示す.

表- 6を見ると，多くのモード形で鋼製支承モデ ルで大きな值が得られており，モードによっては （100m 鉛直 4次）ゴム支承の採用により一般化質量 が半減しているものもある.

（2）複素固有值解析結果

銅製支承とコ“支承の特性差を減衰の観点から見 るために, 前述の両解析モテルに対して複素固有値 解析を実施した．鉛直モ一ドに着目した解析結果を 表-7，8に示す.

龬製支承のモーダル減衰が約 $2 \%$ 状態であるの に比し，ゴム支承では $2 \%$ \%回るモードが多く， モードによっては，1\%を下回る場合 $(100 \mathrm{~m}, 4$ 次 $)$ む ある.これは，鋼製支承では支承での減衰が摩擦に よるものであり，支承の機構（鉛直モ一ドに対して は，必ず回転変位すること）がモードによる減衰差 を生み難いことに比へ，ゴ枝承では，振動モード 図からも読みとれるように，ゴム支承の減衰が発生 する（ゴムの剪断変形が発生する）方向への変形が 鉊直モ一ドからは発生し難く, その程度も振動モ一 ドにより変化することに起因している.

\section{（3）振動応答解析結果}

本説では，前節までに述べた支承特性差に起因す る振動特性の差が, 具体的な振動応答（たとえば, 交通振動に対する応答）に対してどの程度の差を及 ほすすかを見るための検討を行った。

解析は，両支承モテルに対して各振動モードの最 大振幅位置に単位荷重の加振（振幅 : 1tf, 振動数は
対応するモードの固有振動数）を行い，その応答振 幅を比較した．解析結果を, 図-3及び図-4に示す. 表には，各応答観測位置の振幅に加え，ゴ支承と 銅製支承の比を示した.

単位振幅加振に対する応答を見ると，振動モード 形の節となる点付近の比は，大きくなっているが, これはモードの小さいところでの比であるため, モードの腹付近での比較が必要になる.

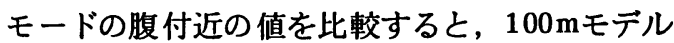
の側径間1/4点付近では, モードの腹付近であるに 屯関わらずゴム支承モデが 4 ～ 6 倍程度の応答振 幅を示している.

このように，ゴム支承の採用によって，モードに よっては単位調和加振に対する応答振幅が大幅に大 きくなる場合があることが明らかになった。

この現象は, 前述の固有振動特性や減衰特性を含

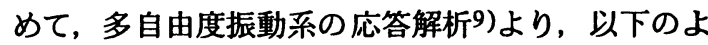
うに説明できる.

全体系の運動方程式を

$$
[\mathrm{M}] \ddot{\mathrm{i}}+[\mathrm{C}] \mathrm{u}+[\mathrm{K}] \mathrm{u}=\{\mathrm{F}\}
$$

で表し，近似的に

$$
\left\{\phi_{s}\right\}^{\mathrm{T}}\left[\mathrm{CK} \phi_{\mathrm{r}}\right\}=0 \quad(\mathrm{~s} \neq \mathrm{r})
$$

が成り立つと仮定すると, 調和外力による振動応答 qは,

$$
q=\frac{1}{\omega_{0}^{2} \mathrm{~F}_{\mathrm{g}}} \frac{1}{\sqrt{\left(1-\frac{\omega^{2}}{\omega_{0}^{2}}\right)^{2}+\frac{4 \mathrm{~h}_{\mathrm{g}}^{2} \omega^{2}}{\omega_{0}^{2}}}}
$$

で表される.

ここに，[M]:質量マトリクス，[C]:減衰マトリク

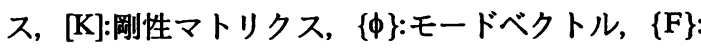
外力ベクトル, $\mathrm{u}$ : 変位ベクトル, $\mathrm{M}_{\mathrm{S}}$ :一般化質量, $\mathrm{F}_{\mathrm{S}}$ :一般化外力, hg: 一般化減衰, $\omega \mathrm{o}$ :固有振動数, $\omega:$ 加振振動数 である.

固有振動数で加振した場合には， $\omega=\omega_{0}$ より， 振動応答は

と表される.

$$
q=\frac{F_{g}}{2 \omega_{0}^{2} M_{g} h_{g}}
$$

ここで，振動応答の差が比較的大きかった $150 \mathrm{~m}$ モデルの鉛直 4 次モードで, 要素となる振動パラ メー夕を比較すると表-9のようになる．両者の比 から応答振幅の比を推定すると, コム支承の採用に より，応答振幅は約1.7倍となる.一方，この振動 モードの応答解析結果は加振側側径間 $3 / 4$ 点で 1.77 となっており概ね一致している. 

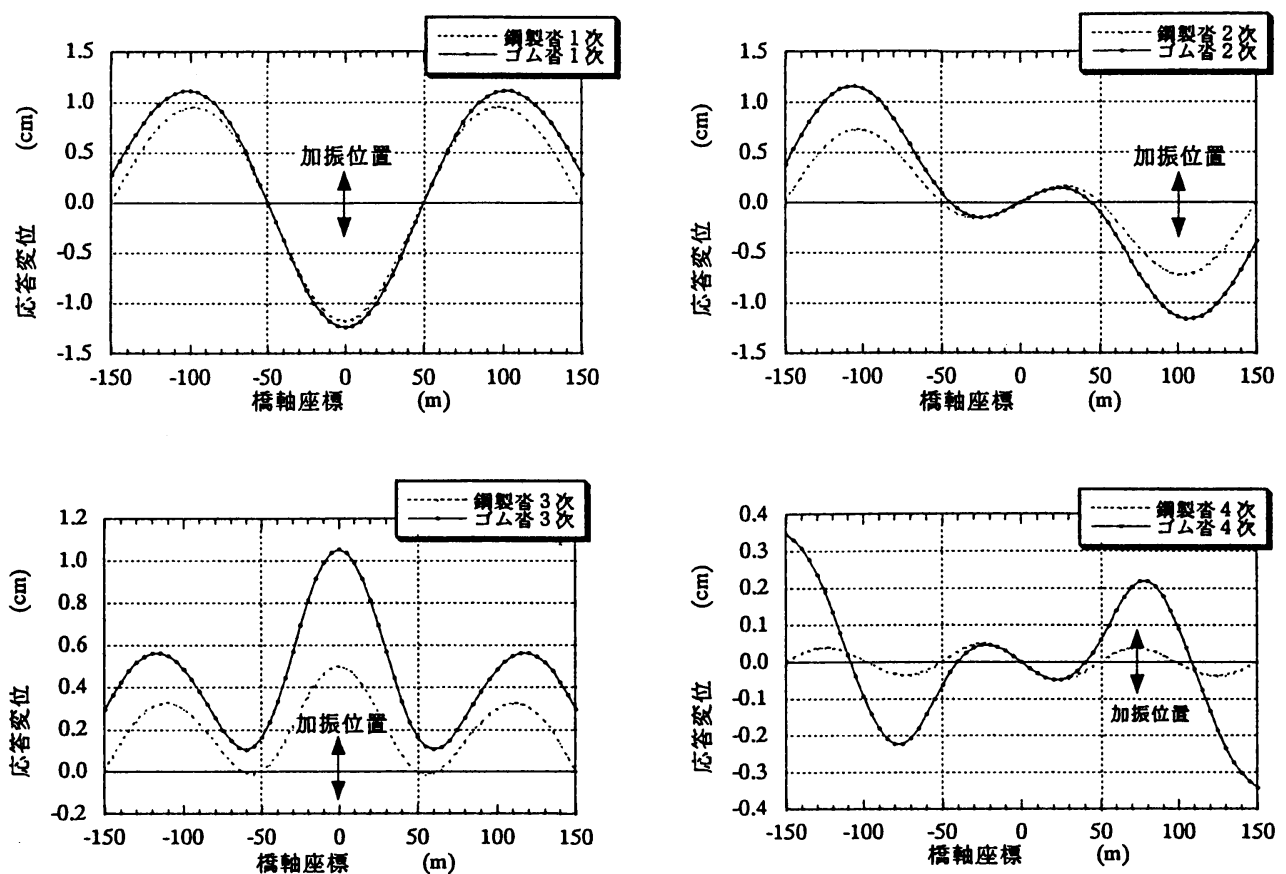

図-3 単位調和外力（振幅 : 1tf, 振動数 : 各モードの固有振動数）に対する応答振幅 (100mモテル)
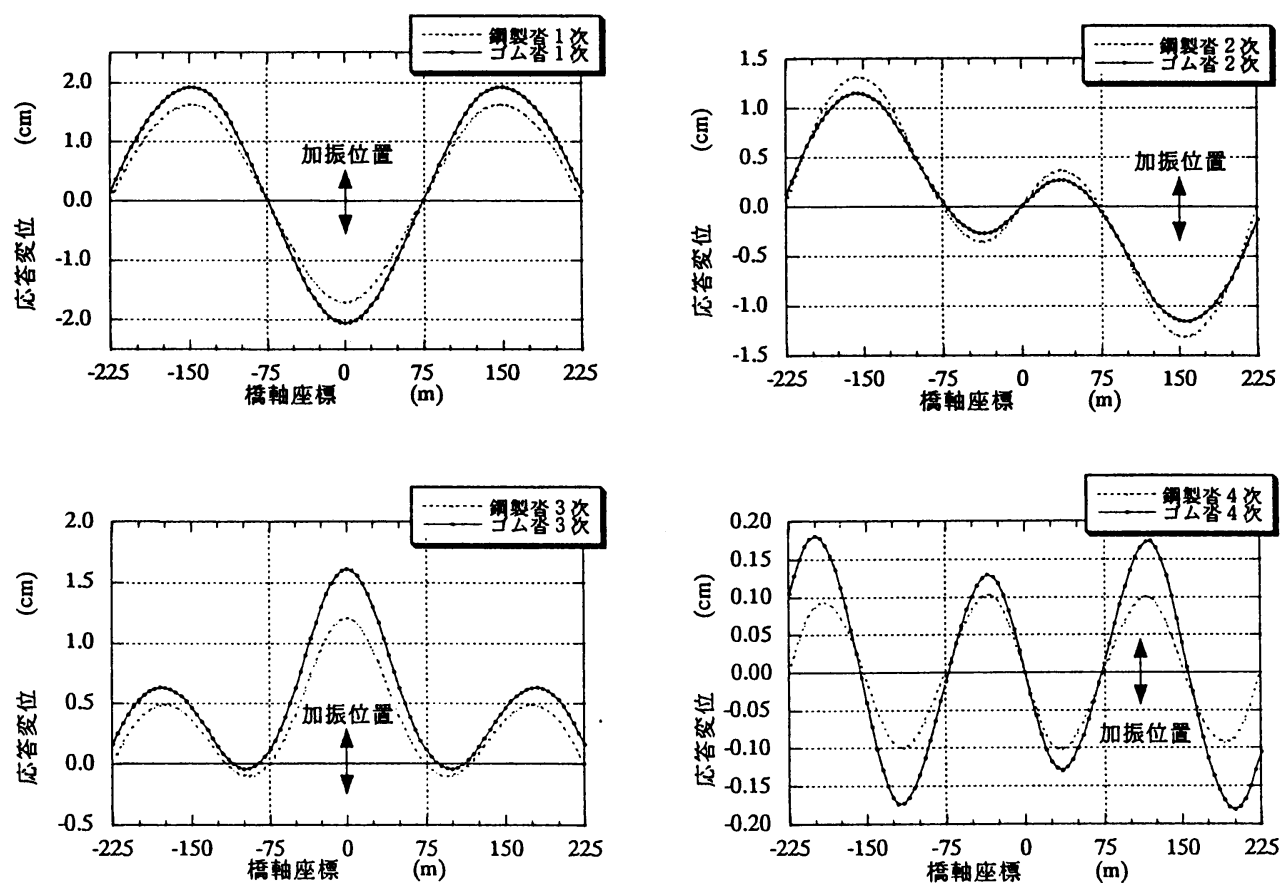

図-4 単位調和外力（振幅 : 1tf, 振動数 : 各モードの固有振動数）に対する応答振幅（150mモテル） 
表-9 振動パラメー夕比較 $(150 \mathrm{~m}, 4$ 次モード)

\begin{tabular}{|l|r|r|c|}
\hline & 鋼製支承* & ゴム支承 & ゴム/銅 \\
\hline 振動数 $(\mathrm{Hz})$ & 1.54 & 1.4 & \\
\hline$\left(\omega^{2}\right)$ & 93.6 & 77.4 & 0.826 \\
\hline 一般化質量 & 221.9 & 197 & 0.888 \\
\hline 減衰 $(\%)$ & 2.032 & 1.643 & 0.809 \\
\hline
\end{tabular}

同様な比較は, 両モデルの他のモードに付いても可 能である.

以上の解析結果から，鋼製支承とゴム支承との支 承差は, 固有振動数や振動モード形の差となって現 れ, 振動応答はモードによっては固有振動数, 減 衰, 及び一般化質量の低下と併せて振動応答を助長 させる原因となることが明らかとなった。

\section{まとめと今後の課題}

鋼製支承から免震支承への置き換えが橋梁の固有 振動特性や振動応答特性に及ぼす影響について基礎 的な考察を加えることを目的として，こく一般的な 橋梁諸元に対して簡単なモデルを用い，支承部（銅 製支承，積層型ゴム支承）の構造の差がこれらの振 動特性に与える影響を検討した。

検討の範囲では，ゴム支承の採用により，固有振 動数, 減衰及び一般化質量が低下し単位調和入力に 対する振動応答が増大するモードの存在が明らかと なった。弾性支承の採用にあたっては, 地震力の分 散のみでなく振動の防止にも配虑する必要がある.

今後, 両支承の変形特性や減衰特性を定量的に評 価し、これらの非線形性を勘案した解析を進めてい く必要がある.
謝辞：本研究は鋼橋技術研究会 耐風制振設計研究部 会の研究活動の一環として実施されたものである。 ここに記して関係各位に謝意を表す。

\section{参考文献}

1）(財）日本道路協会：「兵庫県南部地震により被災し た道路橋の復旧に係る仕様」の準用に関する参考資 料（案），1965年6月.

2) 山本泰幹, 森清, 稲田 育朗 : 密閉ゴム支承の活荷重 挙動に関する実橋調査, 土木学会第50回年次学術講演 会I-333，1995年9月.

3) 北村隆里, 小林潔, 田䳋 俧: ゴム支承への取替効 果に関する鋼桁橋の実橋計測, 土木学会第50回年次学 術講演会I-334，1995年9月.

4) 田嶋 仁志, 佐藤 克寿, 楿 義規 : 鋼I析橋のゴム沓交換 による交通振動計測，第21回日本道路会議論文集, 1994年.

5) 長尾彰洋, 佐藤弘史, 今野久志 : コム支承による交 通振動軽減対策試験について, 土木学会第49回年次学 術講演会I-508，1994年9月.

6)（社）日本橋梁建設協会：デザインデータブック， 1993年.

7)（財）日本道路協会：道路橋示方書同解説，1996年.

8)（財）日本道路協会：道路橋耐風設計便覧, pp.102, 1991年.

9) 片山 恒雄, 宮田利雄, 国井隆弘，構造物の振動解析， 技報堂出版，1979年11月。

(1998.3.2 受付)

\title{
COMPARATIVE VIBRATION STUDY OF GIRDER BRIDGES WITH RUBBER BEARINGS AND STEEL BEARINGS
}

\author{
Hitoshi YAMADA, Shigeki SAWADA, Shuji SHINOHARA and Kohji KAZAMA
}

After the Hyogo-Ken Nanbu Earthquake occurred, the steel bearings underneath the girder bridges came to be substituted with rubber bearings in order to prevent seismic damage to the bridges. However, in this change of design, the concern of vibration increased by response amplitude has been overlooked and, therefore, the new design (with rubber bearings) had to be verified safer for also normal traffic conditions. In the process of analysis, data were collected from three span girder bridges those are equipped with only rubber bearings or steel bearings. In a consequence of analysis, it was revealed that rubber bearings caused not only damping difference but also the difference of vibration mode shapes, which was accountable enough for the phenomena that response from unit sinusoidal load of rubber bearings exceeded that of steel bearings. 